\title{
New Orleans'da Bir Don Quijote : A Confederacy of Dunces Romanı
}

\author{
A Don Quixote in New Orleans: A Confederacy of Dunces
}

\section{Esra Öztarhan'}

Öz:

Don Quijote romanı dünya edebiyatında kendisinden sonra gelen birçok eseri çeşitli yönlerden etkilemiştir. Özellikle yarattığı kahraman prototipiyle birçok edebi esere ilham kaynağı olmuştur. Bu, kendi hayallerinin peşinde koşan, idealist ve içinde yaşadı ̆̆ toplumla çelişen bir kahraman örneğidir. Don Quijote'dan yüzyıllar sonra, bambaşka bir coğrafyada basılan A Confederacy of Dunces romanı da birçok açıdan bu ilk örnek ile benzerlikler taşır. 1980 yılında New Orleans'ta geçen bu roman içinde barındırdığı pikaresk, karnavalesk ve grotetesk ögeler ile Cervantes'in romanının adeta yeniden yazılmış halidir. Özellikle yaratılan kahraman prototipiyle Don Quijote'yi anımsatır. Bu romanın baş kahramanı Ignatius da aynı Don Quijote gibi bir pikarodur. $\mathrm{O}$ da kendi ideal dünyasında yaşamaktadır ve çevresindeki herkesin, yani "alıkların” ona karşı olduğunu düşünür. Ayrıca her iki romanda da ikili karşıtlıklar romanların karnavalesk tarafını ortaya çıkarır. Hayal, gerçek, delilik, akıl...gibi zıt durumlar kahramanın başına gelen maceraların ana eksenini oluşturur. Böylelikle toplumda neyin normal neyin normal olmadığının eleştirisi yapılır. Son olarak her iki roman da birer grotesk realizm örneğidir. A Confederacy of Dunces romanında da kahraman birçok grotesk öğe ile tarif edilir. Romanda topluma garip gelen dış görünümü, davranışları ve abartılı beden faaliyetleri ile

Dr. Öğretim Üyesi. Ege Üniversitesi, Edebiyat Fakültesi, Amerikan Kültürü ve Edebiyatı Bölümü. esraoztarhan@ yahoo.com 
anlatılan kahraman da bir grotesk realism örneğidir. Aynı zamanda kahramanın başarısızlıklarla geçen maceraları da onu adeta yirminci yüzyılda, New Orleans'da yaşayan bir Don Quijote yapar.

Anahtar sözcükler: Don Quijote, A Confederacy of Dunces, pikaresk, karnavalesk, grotesk

\begin{abstract}
:
Don Quixote had been a pioneering example in world literature to many literary works in different aspects. It had especially been an inspiration to other literary protagonists since its publication. This hero prototype is an idealist person who chases its dreams as opposed to the reactions from the society. He has difficulties in adapting to the world and society he lives in. Hundreds of years later, in a completely different geography, a modern novel resembles this hero prototype which was created by Cervantes. A Confederacy of Dunces is set in 1980s New Orleans. He is a picaro just like Don Quixote, thinking that the "dunces" are in a confederacy against him. In both novels there are many carnivalesque aspects like dualisms of madness versus insanity, reality versus illusion. This way both novels criticize what is normal or not in the society's expectations. Lastly both novels are examples of grotesque realism. They have unfamiliar outer appearances, exaggerated bodily functions. Moreover they are depicted as looser dreamers in both novels. Therefore A Confederacy of Dunces's hero can be regarded as a Don Quixote walking in the streets of New Orleans in twentieth century.
\end{abstract}

Keywords: Don Quixote, A Confederacy of Dunces, picaresque, carnivalesque, grotesque

John Kennedy Toole'un A Confederacy of Dunces roman1, yazarın 1969'daki intiharından çok sonra, 1980 yılında basılmış ve Pulitzer ödülünü kazanmıştır. Bu bir yazara ölümünden sonra verilen ilk Pulitzer ödülü olma özelliğini taşır. Kitabın başkahramanı olan Ignatius Reilly annesiyle New Orleans'da yaşayan, otuzlu yaşlarında ve işsiz güçsüz bir adamdır. Ignatius bütün gün evde oturup ortaçağ hakkında kitaplar okuyup, defterlere bu konu hakkında denemeler yazmaktadır. Bir gün sokakta annesini beklerken onun garip kıyafetinden şüphelenip kimliğini soran polis memuruyla olan kavgası, bu romanı oluşturacak olan maceraların başlamasına yol açar. Ignatius ve annesi polisten kaçarlar. Bourbon caddesinde biraz zaman geçirirler, ancak yolda giderken kaza yaparlar. İşte bundan sonra, arabanın maddi hasarını ödemek için paraya ihtiyaç duydukları için annesi ondan çalışmasını ister. Aylakça yaşadığı evinden ayrılmak zorunda kalmak, iş bulmakta yaşadığı zorluklar, yani kısaca dış dünyaya alışmaya çalışmak romanın ana eksenini oluşturur.

Walter Percy A Confederacy of Dunces romanını yazarın ölümünden sonra, yazarın annesinin ısrarları sonucu okumuş ve yayınlamaya karar vermiştir. Percy, kitabın önsözünde, bu roman kahramanının hiçbir edebiyatta öncüsü olmadığını öne sürer. Ona göre, Ignatius: “İnanılmayacak kadar kılıksız, çılgın bir Oliver Hardy, şişman bir Don Quijote, aksi huylu 
bir Thomas Aquina karışımı"dır (Percy, 1980, s. vi). Aynı zamanda romanın kahramanı obur, tembel, bencil ve çocuksudur. Aslında bu karakter, dünya edebiyatındaki birçok kahramandan izler taşır. Hatta Percy'nin saydıkları yanında, biraz Gargantua biraz da Oblomov'dur. Bu makale, romanın kahramanı Ignatius'un, Cervantes' in Don Quijote eserindeki başkahramanı ile olan benzerliklerini analiz etmektedir. Toole bu romanında pikaresk, karnavalesk ve grotesk öğeler kullanarak yirminci yüzyılda, Amerika'da, New Orleans şehrinde yaşayan bir Don Quijote yaratmıştır.

Öncelikle, Toole'un romanı edebiyatta Don Quijote ile başlayan pikaro geleneğinin bir devamıdır. $\mathrm{Bu}$, toplumla uyum sağlayamayan kahraman prototipidir. $\mathrm{Bu}$ tür kahramanların doğruları ve hayat görüşü çoğunlukla içinde yaşadığı çağ ve toplumla çakışır. Onsekizinci ve ondokuzuncu yüzyıllardaki Amerikan edebiyatını incelediği Quixotic Fictions of USA adlı kitabında Sarah F. Wood pikaroyu şöyle tanımlar: Onların "hayat algısı ve idealleri yaşadığı gerçek deneyimlerle uyuşmaz” (Wood, 2005, s.vi). Roberto Echevarria’ya gore de pikaro geleneğindeki temel anlatı özelliği, kahramanın kendi yaşamını kendi arzularına göre belirlemesi ve buna hiçbir şeyin engel olmamasıdır. Ona göre pikaro edebiyatı "kişinin hayal ve arzularına biraz daha yakın olması için duyulan evrensel isteğin” bir yansımasıdır (Echevarria, 2005, s. 4).

Kendini topluma ait hissetmeyen bir edebiyat kahramanını olarak Pikaro, etrafindaki dünyayı farklı algılar ve ona göre davranır. Aynı Don Quijote gibi, Ignatius da kendine göre yel değirmenleriyle savaşmaktadır. Modern zamanlar ona göre değildir, bu yüzden etrafındaki her şey onu rahatsız eder. New Orleans sokaklarında iş aramak ve uyum sağlayamadığı bir dünyada var olmak da ona göre bir çeşit donkişotluktur. Ignatius'un pikaro yolculuğu, Don Quijote'ninkinin aksine, isteksiz bir yolculuktur. Ama bu yolculuktaki amaçları ve idealleri Don Quijote'ye benzer.

Şövalyelik dönemlerine hayran olan Don Quijote gibi, Ignatius da ortaçağ döneminin altın çağ olduğuna inanır. Artık geri gelmeyecek bu zamanlara olan hayranlığı, onu günümüzdeki her şeye karşı memnuniyetsiz kılar. En büyük uğraşı, büyük kağıtlara yazdığı içinde bulunduğu "yüzyıla karşı iddianame” dir. Orada şöyle yazar: "Ortaçağ sisteminin çökmesiyle, Kaos, Delilik ve Zevksizlik Tanrıları hüküm sürmeye başladı. ...Batı dünyasının gördügü düzen, sakinlik, birlik günlerinden sonra gelen değişim rüzgârları kötü günler getirdi. Kader'in çarkları insanlığa karşı dönmeye başladı" (Toole, 2007, s. 25). Modern zamanlar ve modern yaşam tarzı ona göre değildir. Ignatius: "Ben bu yüzyıla uymayan biriyim. İnsanlar bunu anladıkları için benden hoşlanmıyorlar" diyerek kendini herkesten ayrı tutar (Toole, 2007, s. 52). Modern zamanların sağladığı her şey, örneğin yeni elbiseler almak gibi maddi harcamalar, ona göre "zevk ve ahlaka karşı” bir duruştur (Toole, 2007, s. 13). Aynı şekilde, işe gitmek de bir “sapkınlıktır”'(Toole, 2007, s. 26).

Kahramanın sahip olduğu bir başka özellik, bütün dünyanın kendine karşı olduğu şeklindeki algısıdır. A Confederacy of Dunces'ın başındaki epigraf Jonathan Swift'in Thoughts on Various Subjects, Moral and Diverting adlı eserinden bir alıntıdır: "Dünyada gerçek bir dâhi varsa, bunu anlamak kolaydır, çünkü bütün alıklar ona karşı birlik oluştururlar”. Romanın adı bu alıntıdan gelmektedir. Buna göre, eğer bir kişi yetenekli ve akıllıysa, çevresindekiler tarafından takdir edilmemesi olağandır. Bu bakış açısı Ignatius'un hayatına egemendir. Ignatius, sahip olduğu vasıflar ve idealleri yüzünden herkesin bitmek bilmeyen saldırılarına 
maruz kaldığına inanır. Bu da aynı Don Quijote'ye karşı devamlı tuzaklar kuran ve onun yaşadığı talihsiz olayların sorumluluğunu yüklediği büyücülere benzer. Don Quijote romanda birisiyle tartışırken Latince "stultorum infinitus est numerus" deyimini kullanır (Cervantes, 2008, s. 472). Bu "aptalların sayısı sonsuz" demektir. Don Quixote için de çıktığı idealist yolculukta onu anlamayanlar ve durdurmak isteyenler vardır. Toole'un romanındaki "alıklar birliği” dolayısıyla, adeta Don Quijote’tan bir alıntıdır.

Roman stil olarak da episodik anlatımıyla Don Quijote romanını anımsatır. Kahramanın diğer insanlarla birlikte başından geçen maceraları aynı zamanda romanın bölümlerini oluşturur. Don Quijote İspanya' da yola çıktığında nasıl birçok insana rastlıyorsa, Ignatius da New Orleans sokaklarında rastladığı çeşitli insanlarla olan ilişkileriyle var olmaya çalışır. New Orleans romanda sadece bir şehir değil aynı zamanda bir karakter gibi yer alır. Ignatius'a göre, şehir "medeni dünyanın ahlaksızlık başkenti” dir. Şehir: "kumarbazlar, fahişeler, teşhirciler, İsa-karşıtları, alkolikler, uyuşturucu bağımlıları, fetişistlerle..." doludur ve bunlar yolsuzlukla korunur (Toole, 2007, s. 3). Kendine göre Ignatius'un elitist bir tavrı vardır, kimseleri beğenmez. Aslında polisinden sinema salonu sahibine kadar herkesten nefret eder. Dolay1sıyla evinden ayrılıp, sokaklarda iş aramaya çıkmak onun için bir düşüştür. Ignatius "aktif olarak eleştirdiğim sistemin içinde olmak çok ilginç bir ironi” der (Toole, 2007, s. 46). Don Quijote'nin şövalyelik uğruna bıraktığı evinin aksine, o evini sığınağını bırakıp bu bozuk düzenin içinde olmak istemez. Don Quijote nasıl şövalyelik dönemini bitmesiyle bozulduğuna inandığı dünyada yaşamak zorundaysa, Ignatius da insanlarla başa çıkmaya çalışır. Ona göre, annesi de herkes gibi ona karşıdır, onu çalışmaya zorlaması da bunun bir göstergesidir.

Pikaresk romanların bir başka özelliği ise kahramanlarının sahip olduğu abartılı idealizmdir. Bu bakış açısı çoğu zaman gerçeği de farklı algılamalarına yol açar. Montserrat Gines, Southern Inheritors of Don Quixote adlı kitabında Amerika'nın güney edebiyatını inceler. Mark Twain, Faulkner, Eudora Welty and Walker Percy gibi yazarlarda Mançalı adamın izlerini sürer. $\mathrm{Bu}$ yazarlara Toole romanını eklememiş olsa da, güneyli yazarlara ait birçok saptama adeta Ignatius'u anlatır. Kendini şövalye zanneden, İspanya'da güçsüzleri korumak için dolaşan Don Quijote gibi, Ignatius da kendini bu yüzyılda "teoloji ve geometri için savaşan bir haçlı" gibi görür (Toole, 2007, s. 200). Kendisinin bozulmuş modern dünyayı iyileştirmek gibi bir misyonu olduğunu söyler. Aynı Don Quijote gibi onun da gerçeği algılaması bozuktur. Bir ortaçağ kitabından öğrendiğini uygular: "Bu adil bir adamın adil olmayan toplumdaki durumudur" der (Toole, 2007, s. 166). O da bir çeşit şövalyelik peşindedir ve bu uyum sağlayamadığı dünyada, çevresindekileri kurtarmak ister. Ignatius, çalıştığı fabrikada patronlara karşı sabotaj örgütler. Bütün ezilenlerin yanındadır. Hatta kendisinin Afrikalı Amerikalıları çok iyi anladığını, çünkü aynı onlar gibi Amerikan toplumu dışında olduğunu öne sürer (Toole, 2007, s. 105).

Gines, bu edebi prototipin gerçeği yanlış algılamasının aslında beğenmediği gerçeği değiștirme isteğinden kaynaklandığını söyler. Dolayısıyla kahramanlar da etraftan gelen tüm eleştiri ve karşı koyuşlara rağmen kendi ideallerine sıkı sıkıya sarılırlar (Gines, 2000, s. 1). Gines'e göre bu tür bir idealizm hem hayali hem de çok güçlüdür. " Hayalidir çünkü, tanımı itibarıyla, fantezi dünyasına aittir ve tarihi gerçeklik içinde mümkün değildir. Yok edilemez, çünkü eleştirilerden etkilenmez ve özgünlüğünü sorgulayan her girişime karşı gelir” (Gines , 2000, s.1). Bu tür kahramanlar "hayal alanında yolculuk ederler" (Gines, 2000, s. 154). 
Ignatius da aynı Don Quijote gibi gerçeği algılamakta direnir. Bu da onu aynı Cervantes'in kahramanı gibi, gerçek dünyada daha da bocalamaya iter. İki romanda da birçok macera ve komedi unsuru bu yanlış algılamayla ilgilidir. Her iki kahraman da çok fazla okudukları için gerçek dünya ile ilişkileri bozulmuştur. Don Quijote çok fazla şövalye romansı okumuş, Ignatius ise ortaçağ metinleri ile ilgilenmiştir. Onlara göre şövalyelik dönemi ve ortaçağlar altın çağlardır. Don Quijote'un misyonu belirlidir, şöyle der:

Tanrı beni bu demir çağında, altın çağı dediğimiz çağı geri getirmem için yarattı. Benim kaderim tehlikeler, büyük kahramanlıklar, yiğitliklerdir... Yaşadığım bu çağda öyle büyük, akla sığmaz kahramanlıklar göstereceğim ki, geçmiş çağlarda yaşamış bütün o gezgin şövalyeler güruhunun yaptığı en parlak işler, gölgede kalacak (Cervantes, 2008, s. 160-61).

Aynı şekilde Ignatius da benzer cümleler kurar:

...yazma yeteneğimi geliştirmek için gençliğimi herkesten uzak, yapayalnız düşünerek, çalışarak geçirmemin sebebi şair Milton’a özenmemdi. Annemin aşırı ölçüsüzlüğü beni şövalyelere yarışır bir biçimde dünyaya zorla itekleyiverdiği günden beri... bu işçileri desteklemek için bir şeyler yapabileceğimden eminim. Toplumsal bir haksızlık karşısında korkakça davrananlara katlanamam. Günümüzün sorunları ancak gözü pek ve köktenci bir kararlıkla çözülebilir (Toole, 2007, s. 107-8).

Don Quijote gibi, Ignatius da ona göre yanlış olan toplumu değiştirmek için savaşmayı kendine görev edinir.

Her iki kahraman da etraflarındaki gerçek dünyaya direnirler, kendi yarattıkları dünyadan çıkmak istemezler. Don Quijote'nin devlerle savaştığını sandığı ünlü macerasında, aslında yel değirmenlerine saldırır. Bu roman "yel değirmenleriyle savaşmak", yani sonunda kazanılmayacak savaşların ya da boş ideallerin peşinde koşmak anlamındaki deyimini neredeyse bütün dillere kazandırmıştır. Don Quijote, her macerada yaşadığı yanlış anlaşma ve hatayı bir şekilde kendine göre mantıklı bir açıklamayla destekler. Örneğin yel değirmenlerini ona böyle gösteren, onu yenmek isteyen büyücülerdir. Ignatius'a göre de bütün New Orleans şehri onu yok etmek için işbirliği içindedir. Ayrıca "Talih” de onun varlığı ve mutluluğunu yenmek için sürekli onunla savaş halindedir. Başına gelenleri hep kendi görmek istediği gibi yorumlar.

Her iki romanda da kahramanlar, kendi dünyalarında yaşarlar. Olayları yanlış algılarlar, insanları yanlış yargılarlar ve kendilerini olduklarından farklı tanıtırlar. Onların dünyas1 yanılsamalardan oluşan bir ideal dünyadır. Bu dünyada başlarından tatsız olaylar geçse de, kahramanlar deli hayalciler olarak adlandırılsa da, bu bitmeyen bir arayıştır onlar için. Echevarria'ya göre Don Quijote “bireyin seçme, algısına göre yaratma ve gerçeği hissetme özgürlüğüdür” (Echevarria, 2005, s. 20). Kahramanlar deliliğe ve idealizme sığınıp kendilerine dış dünyanın baskısından özgür bir var olma alanı yaratırlar.

Geleneksel Mardi Gras karnavalının şehri New Orleans'da geçen bu roman ayrıca sahip olduğu karnavalesk öğeleriyle de Don Quijote’ye benzer. Zaten şehrin kültürü de karnavalı ve maskeli baloları, kostüm değişiklikleriyle, normal hayat akışını değiştirir. Mikhael Bakhtin Rebelias and His World adlı eserinde karnavalı, gerçek yaşamın kurallarının askıya alın- 
dığg1, topluluğun eşit olabildiği ve herkesin gerçek kimliklerini gizleyerek özgür olabildiği bir durum olarak tanımlar (Bakhtin, 1984, s. 10). Karnaval var olan kuralları ve düzeni sarsmak için "üsttekinin altta, içtekinin dışa, öndekinin arkaya çıktı̆̆ı" bir dünya yaratır (Bakhtin, 1984, s. 11). Bakhtin'e göre, karnavalın özgürleştirici etkisi en önemli özelliklerinden biridir. Bunu da ciddiyeti ve resmiyeti bozarak yapar. Edebiyatta anlatıya kahkahayı getirmek bir tür özgürleştirici etkidir (Bakhtin, 1984, s. 49).

Karnavaleskin olmazsa olmaz özelliklerinden biri var olan düzeni yıkmak için ikilikleri kullanmasıdır. Her iki romanda da hayal ve gerçeğin bir arada bulunması ve çarpışması buna en iyi örnektir. Don Quijote'deki ikilik, kahramanın hayal dünyası ile gerçek dünya arasındaki uyumsuzluktur. Roman boyunca, çevresindeki insanlar Don Quijote’ye gerçek dünyay1 göstermeye ve onu bu fantezi dünyasından uzaklaştırmaya çalışırlar. Etrafındaki kimse onun idealizmini anlayamaz, daha da kötüsü takdir etmezler. Sadece Sancho, romanda materyal dünyanın temsilcisi olduğu halde ya efendisiyle çok vakit geçirdiğinden ya da onu mutlu etmek için zaman zaman onun hayal dünyasına girer. Jale Parla'ya göre bu materyalizm ve idealizmi diyalektiği romana egemen motiftir (Parla, 2000, s. 10). Romanda bazen, Don Quijote'nin etrafındaki kişilerin de romanın kahraman gibi hayallere katıldığg görülür. Sırf onunla alay etmek için gerçeği onun gibi algıllyormuş gibi yaparlar. Kendilerini soylu dük ve düşes kılığına sokarlar. Ancak bu hayal dünyası oyununa katıldıkları an kendileri de Don Quijote kadar "deli” olurlar. Örneğin dördüncü bölümde, Cervantes: "Bu sözleri duyan ve konuşan tuhaf adamı gören tüccarlar durdular. Hem görünüşünden, hem sözlerinden, deliliğini hemen fark ettiler ama belli etmediler" diye yazar (Cervantes, 2008, s. 68). Başka bir macerada, hanın sahibi Don Quijote'un hayal dünyasıyla alay etmek için onu şövalye ilan eder. Bu törende kutsal kitap yerine basit bir defter kullanır. Bu törende ona iki fahişe soylu kadınlarmış gibi yardım ederler. Butamamen onunla alay etmek için kurguladıkları bir parodidir: "Kadın büyük bir beceri ve ciddiyetle bu işi yaptı; törenin her anında gülmekten patlamamak için çok ciddi olmaları gerekiyordu" (Cervantes, 2008, s. 64). Ancak amaçları onu kandırmak olsa bile, kendileri de bu oyunun bir parçası olurlar. Bütün bu örneklerde görüldüğü gibi romanda, kimin gerçek dünyada kimin hayal dünyasında olduğu çoğu zaman karışır. Yani gerçek ve hayal yer değiştirirler.

Confederacy of Dunces romanında da kahramanın hayal dünyası çevresindekiler tarafından anlaşılmaz. Ignatius'u garip fikirleri, davranışları, tuhaf dış görünüşü, saplantıları ve hayat görüşü yüzünden aşağılayanlar, aslında kendileri daha da gariptir. Zaten Ignatius'a göre New Orleans şehri topluma aykırı insanlarla doludur (Toole, 2007, s. 4). Onu topluma uyumsuz gören herkesin, annesi de dâhil kendi kusurları ve uyumsuzlukları vardır. Alkolik, aşırı dalgın yaşlı iş arkadaşı, kostüm giymekten hoşlanan polis memuru... gibi karakterlerin hepsi en az Ignatius kadar kendine hastır. Roman böylelikle aynı Cervantes'in romanında olduğu gibi ideal olan kahramanla, olmayanı, normalle normal olmayan olarak addedileni ikili karşıtlıklarla sunar. Yazarlar tarafından kullanılan karnavalesk ikilik, gerçek ile hayali yer değiştirebilir ve altüst edilebilir kavramlar haline getirmek için kullanılmıştır. İnsanların algıları ve yargılarının nasıl da önyargılı ve taraflı olduğunu göstermek için yapılır.

Romandaki bir başka ikilik ise delilik ve akıllılık karşıtlığıdır. Bütün karnaval imgeleri de bu ikiliğin üzerine kurulmuştur: Doğum, ölüm, aptallık, bilgelik, kutsama, lanetleme... gibi. 
Cervantes'in romanındaki temel sorun da zaten Don Quijote'un deli mi akıllı mı olduğudur. Çoğu zaman etrafindakiler nasıl olur da böyle akıllı ve okumuş birinin bu kadar çılgın olabileceğini merak ederler. Bunu doğrularcasına bazen Don Quijote Sancho Panza’ya öyle zekice tavsiyelerde bulunur ki herkes deliliğini unutur, böyle davranarak rol yaptığına ikna olur. Aynı ikilem Ignatius için de geçerlidir. Hayli eğitimli ve ortaçağ tarihi hakkında donanımlı biri olarak, Ignatius'un saçma sapan konuşması ve irrasyonel davranması herkesi şaşırtır. New Orleans’ta 1960 yılında, ortaçağ ile ilgili konuşması ve ideal olarak gördüğü bu dönemden başka hiçbir şeyi beğenmemesi herkesi şaşkına çevirir. Jonathan Simmons’a göre, “o gerçek bir dahidir, bu yüzden de alıklar onu anlayamazlar" epigrafindaki paradoksal anlamın romanı bir karnavalesk roman yapmaya yeterli olduğunu öne sürer (Simmons, 1989, s. 34-5). Simmons'a göre, normalde bir kişinin dahi olup olmaması yaptığı işler ya da söylediği sözler ile doğrulanır. Ancak kitaba da adını veren bu alıntıda, bir kişinin dahi olup olmaması, toplumun ona karşı olan tepkisiyle ölçülür denmektedir. Dahi ve alıklar, iki ayrı tarafı oluştururlar. Bu gönderme Ignatius'u karnavalesk bir figür yapar. Simmons'a göre, etrafında aşağıladığı her şeyin ve herkesin bir yansıması kendinde görülür (Simmons, 1989, s. 34-5). Bu saçma durum da karnavaleskin bir parçasıdır. Aynı zamanda da Toole'un yaptığı toplumsal hicivi gösterir.

Kahramana ait benzer bir bakış açısı Don Quijote'ta da görülür. Don Quijote hem etrafındakileri beğenmez hem de kendisinin bilinçli olarak bu sisteme karşı olmak için deli olduğunu kabul eder: "Benim tasarımın inceliği burada. Belli bir sebeple çıldıran gezgin şövalye, özel bir övgüyü hak etmez; mesele sebepsiz delirmek ve sevgilime, sebepsiz yere bunu yapıyorsam, sebebi olunca ne yapacağımı düşündürmek. ...Deliyim, deli olmak zorundayım” (Cervantes, 2008, s. 208). Ancak bu ince düşünceyi aynı kimsenin, Igantius'u anlamaması gibi, kimse anlamaz. Delilik rasyonel düşünceye karşı olmak, herkesin davrandığg ve düşündüğünden farklı davranmak da karnavalın bir başka özelliğidir. Bu da özgürleştirici bir durumdur.

Don Quijote'un deliliği, kendi içinde tutarlıdır, kurallarla belirlenmiştir. Onun için kitaplarda yazan şövalyelik kuralları ve geleneklerine uygun davranmak her şeyden önemlidir. Onun için şövalye kitapları nasıl yaşaması gerektiğinin kılavuzudur. Örneğin romanın başındaki gezgin şövalyeye dönüşürken, bu kitaplara göre kendini oluşturur. Her gezgin şövalyenin bir atı ve sevgilisi olmalıdır diyerek her şeyi kuralına göre uydurur. Başka bir yerde: “ Ben sular tanrısı Neptün değilim; akıllı olmadığım halde kimsenin beni akıllı sanması için de uğraşmıyorum” diyerek yine bilinçli davrandı̆̆ını belirtir (Cervantes, 2008, s. 458).

Myths of Modern Individualism kitabında da Ian Watts'ın belirttiği üzere, Cervantes'in roman kahramanı "delilik konusunda öz bilinçlidir” (Watts, 1996, s. 85).

Ignatius da işyerinde hiçbir kurala ve ondan beklenen davranışlara uymaz. Giydiği k1yafetlerle ve toplum içinde davranılmayacak şekilde davranmakla her zaman toplumdışı bir kahramandır. Onun kendi doğruları her zaman toplumsal baskıdan daha üstündür. Don Quixote and the Poetics of the Novel kitabında deliliğin "sonuçlarına katlanmak zorunda olmadan sahip olunan özgürlük ve saçmalık" olduğu belirtilir (Martinez- Bonati, 1992, s. 124-5). Her iki romanda da kahramanların delilik ve akıllılık arasında gidip gelmeleri onlara toplumsal kurallardan kurtulma ve özgürleşme imkânı yaratır. Bu karnavaleskin var olan kurallara karşı gelme özelliğidir. Bir gün için bile olsa, bütün karnavallar, toplumsal roller ve kuralları yıkmayı amaçlar. 
Karnavalesk durumun yarattığı bir başka özellik ise grotesktir. Grotesk kabaca komik, tuhaf, doğal olmayan ve anormal anlamlarına gelir. Uyumu ve dengeyi bozan, toplumca beklenen norma karşı olan bütün sapmaları içerir. Ayrıca bedenin yemek, içmek, boşaltım yapmak, seks ve sindirim gibi bütün temel ihtiyaçlarının abartılı bir şekilde gösterilmesini de kapsar. $\mathrm{Bu}$ bedensel aktivitelerin kullanılması, anlatının ideal, ruhani ve soyut bölümünün alçaltılmasına yol açar. Bakhtin'e buna "yozlaşma” denir. Rabelais'ın kitabını incelediği eserinde, maddi bedenin bu şekilde sunulmasını "grotesk idealizm" diye adlandırır (Bakhtin, 1984, s. 18-9). Alt bedene ait organların ve ihtiyaçların kullanılmasının yanı sıra, grotesk anlatı aynı zamanda konu olarak delilik, anlatım türü olarak ironi ve hiciv, karakter seçimi olarak ise sıradan insanın temsil edilmesi gibi özellikler de taşır. Her iki romanda da bu özellikler gerçek, maddi, insani öğelerin nasıl ideal, soyut ve insan dışı özelliklere üstün geldiğini göstermek için yazarlar tarafından özellikle kullanılır. Romanlardaki kahramanlar, fiziksel dış görünüşleri, bedenleri ve bütün bedensel faaliyetleri ile kullanılarak yine özgürleştirici bir etki yaratılır. Bakhtin'e göre, Don Quijote romanında grotesk idealizmin bir edebi araç olarak kullanılma sebebi, ideal olanı yıkmaktır. Roman artık şövalyelik döneminin bittiğini, sadece ideal kahramanların değil, tüm insani özellikleri ile kaybedenlerin de kahraman olabileceğini ispatlamaktadır. Bakhtin ayrıca romandaki kaleler, fahişeler gibi birçok motifin ve karakterin de grotesk realizm özellikleri taşıdığını söyler (Bakhtin, 1984, s. 20-22).

Öncelikle, her iki romanda da görülen ilk grotesk özellik kahramanların dış görünüşleridir. Don Quijote romanın ilk sayfalarında vücudu neredeyse iskelet gibi zayıf ve sağlıksız tasvir edilir. Cervantes ayrıca, "bir beyni olsa sulandırmaya yeterdi” diyerek kahramanı iyice insan dişı yapar (Cervantes, 2008, s. 59). Kahramanın yüzü ile de birçok yerde alay edilir. Ona "mahzun yüzlü şövalye" derler (Cervantes, 2008, s. 158). İnsanların da onunla ilgili ilk izlenimleri hep onun "iğreti” kılığından dolayı olumsuz ve alay doludur (Cervantes, 2008, s. 57). Don Quijote'nin kendine uydurduğu kâğıttan miğferli, paslanmış zırhlı şövalye kıyafeti de buna örnek olarak gösterilebilir (Cervantes, 2008, s. 53). Don Quijote'nin yanı sıra Sancho Panza da şişman ve kısa olarak bedeniyle ve bitmez iştahıyla grotesk idealizm örneğidir. Zaten adı da kelime anlamı olarak "göbekten ayak "anlamına gelir (Cervantes, 2008, s. 94).

Kennedy Toole'un romanında da groteskin vücut bulmuş hali Ignatius'dur. Simmons'a göre, bu romanda dünya edebiyatındaki komik ve hiciv içeren birçok örneğin etkileri vardır. Ona göre bu kitabı Rebelias'ın, Cervantes'in, Shakespeare ve Swift' in eserleri gibi eserlerden bağımsız anlatmak çok zordur (Simmons, 1989, s. 33). Öncelikle Ignatius'un dış görünüşü aynı Don Quijote gibi hayli iğretidir. Kendi yaşında birinin kıyafet normlarına uymayan bir stili vardır. Özellikle romanda devamlı vurgulanan, kafasından hiç çıkarmadığı yeşil kasketi, aynı Don Quijote'nin miğferi gibidir. Romanın başında kahraman şöyle tasvir edilir:

Etli, balon bir kafanın tepesine sımsıkı geçirilmiş yeşil avcı kasketi. Kasketin iri kulakları, berber eli değmemiş saçlar, o kulaklardan fişkıran ince tüylerle dolu yeşil kulaklıkları, aynı anda iki yönü gösteren dönüş işaretleri gibi iki yanda havaya dikilmiş. Siyah, fırça gibi bıyığın altından dolgun, torba gibi büzülmüş dudakları dışarıya firlıyor, ağzının iki yanında beğenmezlikle ve cips kırıntılarıyla dolu küçük kıvrımlarda son buluyor (Toole, 2007, s. 13) . 
Çoğu insan Ignatius’u ilk gördüklerinde, dış görünüşünden dolayı garip bulurlar. İlk bölümde, polis Mancuso onu şöyle tarif eder: "Çocuk değildi. Komik giyinmiş şişman bir adamdı. Çok şüpheli birine benziyordu... Gerçeği söylemek gerekirse, koca bir sapığa benziyordu... Hayatımda gördüğüm en büyüğüne hem de" (Toole, 2007, s. 14). Başka birisi, onu “ koca bir deli"ye benzetir (Toole, 2007, s. 20). Başka bir seferde ise New Orleans sokaklarında korsan kostümüyle hotdog satarken gören biri ona "hazımsızlık çeken Bette Davis'e" benziyorsun der (Toole, 2007, s. 258). Daha sonra partiye katıldığı bölümde ise onunla "altın küpeli kız" diye seslenirler (Toole, 2007, s. 322). Onun diş görünüşüne yapılan bütün bu birbirinden uyumsuz ve tuhaf benzetmeler onun grotesk beden algısını daha da yapılandırır.

A Confederacy of Dunces romanında birçok yerde, Ignatius'un bedenin büyüklüğüne de referanslar yapılır. Bir seferinde yazar ona "gargantua” gibi diyerek Rebelias'ın grotesk romanına gönderme yapar (Toole, 2007, s. 13). Başka bir yerde ise İncil'deki dev hayvana, yani Behemoth'a (büyüklüğü ve gücü ile karışıklık yaratan yaratık) gönderme yapılır:

Kapı açıldı içeriye Bay Gonzalez'in o güne kadar gördüğü en iri adam girdi. Adam yeşil kasketini çıkarınca, 1920li yıllardaki gibi briyantinle sıkıca kafatasına yapıştırılmış gür, siyah saçları göründü. Yeşil palto çıkınca, Bay Gonzalez dar, beyaz gömleğin içine tıkıştırılmış, halka halka yağları ve bunları boylamasına kesen, iri çiçekli boyunbağını gördü. Bıyığa da briyantin sürülmüş olmalıydı ki ışıl ışıl parlıyordu. Bir de incecik pembemsi, damarlarla kaplı, akıl almaz, mavi sarı̈özleri vardı (Toole, 2007, s. 74).

Onu ilk defa görenlerin tepkileri aynı Don Quijote'u görenlerinkine benzer. Ancak Don Quijote'nin bedeninin aksine Ignatius'un dev bedeni dikkat çeker. Her iki beden de grotesk bir biçimde, insan değillermiş gibi anlatılır. Ignatius fil gibi yürür, balina gibidir, bir su ayg1rına benzetilir. Bu imgeler de oldukça grotesktir. Hatta birkaç defa ellerinden bahsedilirken bir hayvanın pençesi benzetmesi kullanılır, elleri "kocaman pençesini şilteye indirdi" diye tarif edilir (Toole, 2007, s. 59).

$\mathrm{Bu}$ kahramanları grotesk yapan bir başka özellik ise yemek, kusmak, tuvalete gitmek gibi bedensel işlevlerin abartılı bir şekilde anlatılmasıdır. Bakhtin'e göre, maddi bedenin böyle kullanılması, kutsal, normal ve alışagelmiş olanı değersizleştirmesidir. Bu dünyevi ve maddi bedene olan vurgu soyut ve yüce olana karşı bir başkaldırıdır (Bakhtin, 1984, s.1821). Don Quijote' de birçok yerde karakterler anlatıya hiçbir faydası olmadığg halde bedensel işlevleri ile anlatılır. Kahramanların yemek, içmek, cinsellik, tuvalet gibi bedensel ihtiyaçları birçok bölümde açıkça betimlenir. Sancho Panza sahip olduğu iştah ve oburlukla karnavalesk bedenin bütün özelliklerini taşır. Örneğin, Don Quijote'nin yaptığı iksirin, şövalyelere iyi geldiğini öğrenince hemen kendisi de içer. Bunun sonucu olarak ise grotesk bir biçimde betimlenir: "Bu arada bileşim yapacağını yaptı ve zavallı silahtar, hem alttan hem üstten öyle bir çıkarmaya başladı ki, tekrar üzerine uzandığı sukamışından hasır ve üzerine örttüğü çaput işe yaramaz hale geldi” (Cervantes, 2008, s. 142). Bir başka bölümde de benzer anlatım devam eder. Don Quijote ve Sancho Panza birbirlerinin üzerine kusarlar. Cervantes bu sahneyi bütün groteskliği ve detayları ile anlatır:

Sancho o kadar yaklaştı ki, neredeyse gözleri ağzına girecekti. Tam o sırada balsam Don Quijote'nin midesini harekete geçirdi ve Sancho ağzına baktı- 
ğ1 anda midesi, içinde ne varsa, tüfek şiddetiyle dışarı, merhametli silahtarın sakalının ortasına firlattı... O kadar iğrendi ki, midesi altüst olup içini dışını efendisinin üstüne kustu; her ikisi de çiçek gibi oldular (Cervantes, 2008, s. 151).

Kahramanların bu trajik gülünç halleri bir mizah yaratsa da, bedene ait iğrenç sayılabilecek bu ayrıntıların eserde olması, Cervantes tarafından özellikle yapılmış bir kurgudur.

Don Quijote 'de görülen bu grotesk anlatım Toole'un eserinde de yer alır. Her iki kahramanın bedensel özellikleri Ignatius'da birleşir. İştahı Sancho Panza'ya benzemektedir. Odası devamlı yediği ve odada unuttuğu yiyeceklerden kokmuş durumdadır. New Orleans sokaklarında sosisli satmaya başladığı zaman da sattığı sandviçlerden daha fazlasını kendisi yediği için patronu işine son verir. Don Quijote'deki cinsellik ve sindirimle ilgili birçok örnek Toole'un romanında da bilinçli olarak yer alır.

Pazen pijamasının üst kısmını sıyırıp şişmiş göbeğine baktı....karın boşluğundaki supap keyfince kapanarak karnını salıverilmemiş gazla dolduruyordu; kişiliği olan, yaşayan bu gaz bulunduğu yerden nefret ediyordu... Yan yatmış, aşağı yukarı olanca gücüyle hoplayan Ignatius gazın boğazına kadar yükseldiğini hissetti, umutla ağzını açtı, ama çıkarabildiği tek şey, küçük bir geğirti oldu (Toole, 2007, ss. 39-41).

Grotesk anlatının son özelliği de kahramanların kaçınılmaz birer kaybeden olarak anlatılmasıdır. Jale Parla karşılaştırmalı edebiyat incelemesinde Cervantes'in romanının bu özelliğinin özellikle altını çizer. Don Quijote'un her bölümünün kahramanın kör idealizmiyle başlayıp, fiziksel bir dayak yeme, başaramama ile ya da grotesk olaylarla bittiğini savunur (Parla, 2000, s. 61). Romanda kahramanın kendi üzerine vazife olmayan olaylara karışması, şövalyelik ideallerine göre herkesi korumak ve kurtarmak istemesi... gibi sebeplerle başlayan her macerası başarısız biter. Bu maceraların sonları da yine grotesk bir biçimde anlatılır. Örneğin kaldıkları hanın parasını vermeyince hancı tarafından iki kahraman da bir güzel dövülür: “Avluda Sancho’yu battaniyenin ortasına koyup havaya atmaya, karnaval köpeğiyle oynar gibi oynamaya başladılar. Zavallıcık, hoplatılırken öyle çığlıklar atıyordu ki...” (Cervantes, 2008, s. 143).

Don Quijote' de birçok defa da yardım etmek adına yapılan hareketlerin sonucu felaketle biter. Örneğin dayak yemekte olan bir çocuğu kurtarmak için müdahale eden Don Quijote, onu kurtaracağına daha da çok dayak yemesine sebep olur. Ancak kendisine göre başarılıdır: "haksızlığı işte bu şekilde düzeltmişti; kendisi olanlardan pek memnundu" der (Cervantes, 2008, s. 68). İronik bir şekilde Cervantes de, kahramanının becerisizliklerinin farkında olarak bir serüvenin adını “cesur Don Quijote” koyar. Sancho da bugüne kadar, kazandığımız bir savaş olmad1, "Ondan sonra varsa yoksa sopa, varsa yoksa yumruk; bana fazladan bir de yedi okka düştü” diyerek bütün maceralarının sonucunu adeta özetler (Cervantes, 2008, s. 146). Dünyaya adaleti getirmek için yola çıkan kahramanları her bölümün sonunda dayak ya da küçük düşürülmek bekler. Don Quijote'nin hayal ettiği dünya artık var olmadığından, kahraman olarak amacına ulaşamaz ve kaybeder. Gines bu durumu, onun "ilk kendini kandıran modern kahraman” olmasıyla açıklar. Bu yüzden onun serüveni, yanlış anlaşılma, kaybetme, talihsizlik ve paradoksla doludur (Gines, 2000, s. 2). 
Aynı şekilde Ignatius da prototipik bir kaybedendir. O kadar olanaksız planlar yapar ki, asla başarılı olamaz. Örneğin içinde bulunduğu yüzyılı eleştiren "büyük edebi eserini” yıllarca bitiremez. Romanda bu eseri yazma sürecini okuyunca, bunun imkânsızlığı da ortaya çıkar. Beş senedir üzerinde çalıştığı, dev kâğıtlara yazdığı bu eleştiri odasının her tarafını kaplamıştır. Ancak senede sadece beş paragraf yazarak bitirmesi de olanaksızdır. Aynı zamanda iş yerlerindeki çalışma koşullarını değiştirmek için öne sürdüğü hiçbir plan gerçekçi değildir ve yine başarısızlıkla sona erer. Bu ümitsiz çabası da kör idealizminin bir sonucudur. Zaten isminin anlamı da onun yok edici ve grotesk varlığının işaretidir. İngilizcede "ignite" kelimesi, yakmak anlamına gelir. A Confederacy of Dunces, romanında Ignatius Don Quixote gibi girdiği her maceradan bir sorunla çıkar. Aynı Don Quijote gibi dövülür, düşer, rezil olur. Bu tür komedi unsurları da her iki eserin grotesk atmosferine katkı sağlamak için kullanılır:

Denge duygusu hiçbir zaman fazla gelişmemişti, üstelik o şişko çocukluğundan beri hep düşmeye, tökezlemeye, çarpmaya eğilimliydi. ...Ignatius iri kalçaları tabureye dokununcaya kadar yavaş yavaş çömeldi; dizleri neredeyse omuzlarına değiyordu. Sonunda tüneğine yerleşmeyi becerdiğinde, bir raptiyenin üzerinde durmaya çalışan bir patlıcana benzemişti (Toole, 2007, s. 92).

Ignatius da gittiği her yerde sorun çıkarır. Özellikle de başka insanların işlerine karıştığ1 zaman sonuç o insanlar için hep felakettir. Annesi ile gittiği barda garsonla o kadar çok konuşur ki, kız neredeyse kovulacak hale gelir. Barda da "garip” görünüşlü “garip fikirli” adam olarak fark edilir (Toole, 2007, s. 29). Walker Percy romanın önsözünde Ignatius’un macerasını şöyle özetler: "Girdiği her işi kısa sürede çılgınca bir serüvene, gerçek bir felakete dönüştürüyor; öte yandan bütün olup bitenlerin kendi içinde, tıpk1 Don Quijote'de olduğu gibi uğursuz bir mantığı var" (Percy, 1980, s. vi). Ancak bu kahramanlar için kaybetmek ve başaramamak kafalarındaki ideal hayatı yaşamaları ve dünyayı değiştirmelerin engel değildir.

\section{Sonuç}

Don Quijote dünya edebiyatında idealizmin sembolüdür. İçinde yaşadığı toplumla uyum sağlayamayan, kendi doğruları için yaşayan kahraman prototipinin ilk örneklerindendir. Şövalyelik kurallarının artık geçersiz olduğu bir dünyada yaşamak zorundadır ve bu yüzden düzene karşıdır. Onur ve saygının egemen olduğu bir dünya hayal eder. Hayatını bu arayış üzerine kurar. Ancak kahramanın içinde bulunduğu dünya ile hayal ettiği dünyanın çakışmas1, romanın ana sorunsalını oluşturur. Kahramanın kendi doğruları ile imkânsız bir hayalin peşinde koşmayı sürdürmesi ise, hiçbir zaman kazanamayacak olan bir idealizmi simgeler. $A$ Confederacy of Dunces romanı Don Quijote 'den yüzyıllar sonra, bambaşka bir coğrafyada geçse de, Don Quijote’deki pikaresk, karnavalesk ve grotesk gibi bir çok ögeyi barındırır.

Öncelikle, Toole'un kahramanı da yirminci yüzyılda ve New Orleans sokaklarında arayışını sürdürse de, bir pikarodur. Onun da Don Quijote gibi içinde yaşadığı çağa uyum sağlayamaz ve kendi idealleri doğrultusunda yaşamak ister. Yaşadığı yer ve zamana bir eleştiri olarak yazılan bu romandaki kahraman prototipi de bu durumu destekler. Ignatius kendi dünyasında, herkesin ona karşı olduğunu sandığı bir çağda yaşar. Aynı don Quijote gibi abartılı bir idealizm ile yel değirmenlerine karşı New Orleans'da savaşır. 
İkinci donkişotvari özellik ise karnavalesktir. Bu da her iki romanda da kendini anlatımdaki ikili karşıtlıklarla gösterir. Kahramanların idealizmi ve hayal gücü karşısında gerçek dünyanın varlığı bu ikiliklerden biridir. Bir başka ikilik ise kahramanların deli mi akıllı mı oldukları üzerine tartışmadır. Bu özellik her iki romanda da kahramanlara özgürleştirici bir alan yaratır.

Son olarak hem Don Quijote hem de A Confederacy of Dunces romanları grotesk gerçekçilik örnekleriyle doludurlar. Dış görünüşlerindeki farklılıkları ve bedenleri ile abartılı bir şekilde tasvir edilmeleri yönlerinden bu özelliğe uyarlar. Bunun dişında beden işlevlerinin anlatılması da grotesk etki yaratan bir başka özelliktir. Son olarak her iki kahraman da kaybetmeye mahkûm insanlardır. Bütün bu grotesk özellikler de topluma eleştirel bir bakış açısı getirmenin, ideal olanı önemsizleştirmenin bir başka yoludur.

\section{Kaynaklar}

Bakhtin, M. (1984). Rebelias and his world. Bloomington: Indiana UP.

Cervantes S. M. (2008). La Mancha'lı yaratıcı asilzade Don Quijote. (Roza Hakmen, çev.). 11. bas. İstanbul: Yap1 Kredi.

Echevarria, R. G. (2005). Cervantes'Don Quixote: A casebook. Oxford: Oxford UP.

Gines, M (2000). Southern inheritors of Don Quixote. Louisiana: Louisiana State UP.

Martinez- Bonat, F. (1992). Don Quixote and the poetics of the novel. Ithaca: Cornell UP.

Toole, J. K. (1980). A confederacy of dunces. New York: Grove Weidenfeld.

Toole, J. K. (2007). Alıklar birliği, (P. Özgören, çev.) İstanbul: Merkez Kitaplar.

Parla, J. (2000). Don Quijote tan bugüne roman. İstanbul: İletişim.

Percy, W.(1980). Foreword. A confederacy of dunces. John Kennedy Toole. New York: Grove Weidenfeld.s v-vii.

Simmons, J. (1989). Ignatius Reilly and the concept of grotesque in John Kennedy Toole's A confederacy of dunces. Mississippi Quarterly, 43.1, 33-43.

Wood, S. (2005). Quixotic fictions of USA: 1792- 1815. New York: Oxford UP.

Watts, I. (1996). Myths of modern individualism. Cambridge: Cambridge UP. 